\title{
A komplikált gyász felismerése az orvos szemszögéből
}

\author{
Zelena András dr., ${ }^{1,2}$ \\ ${ }^{1}$ Budapesti Gazdasági Egyetem, Külkereskedelmi Kar, Társadalomtudományi Intézet, Budapest \\ ${ }^{2}$ Szegedi Tudományegyetem, Általános Orvostudományi Kar, Magatartástudományi Intézet, \\ Szeged (meghívott előadó)
}

\begin{abstract}
Gyászfeldolgozó csoportból származó két eset ismertetésével arra világítok rá, hogy milyen fontos szerepe van a betegei nonverbális jelzéseire is szenzitív kezelőorvosnak a komplikált gyász, a megrekedt gyászmunka időbeni felismerésében. A tajszámok mögött rejtekező egyéni traumákat és sorsokat ismerő orvosok, sőt a betegek életkörülményeinek részleteit ismerő családorvosok katalizátorai lehetnek a megrekedt gyászmunka folytatásának, s számos pszichoszomatikus tünet mögött fedezik fel a valós traumatogén okot. Mivel a gyászfeldolgozó csoportokkal dolgozó szakemberek a komplikált gyásszal - korábbi, stigmatizáló terminológiával: patológiás vagy torzult gyásszal - küzdők legkülönfélébb hiány- és veszteségtapasztalatainak manifesztumaival találkoznak, ezért komoly szakmai kihívás a sokszor rendkívül heterogén összetételú, igen eltérő veszteséggel és egyéni gyászhabitussal rendelkező egyének csoportmunkáját összehangolni, ami finomra hangolt együttmúködést követel a gyógyítóteam tagjaitól.

Orv Hetil. 2017; 158(36): 1426-1431
\end{abstract}

Kulcsszavak: komplikált gyász, pszichoszomatikus rendellenességek, gyásztámogatás

\section{Recognizing complicated grief from a doctor's point of view}

By reviewing two bereavement support group cases I wish to demonstrate the important role a doctor, also receptive of his patients' non-verbal signals, has in the early recognition of complicated grief and halted grief process. Doctors are aware of individual traumas and destinies, and general practitioners are familiar with the details of their patients' life and home circumstances, could be catalysts for the continuation of the halted grief process. They discover the real cause of trauma behind several psychosomatic symptoms. For professionals working with bereavement support groups and meeting a number of different manifestations of the experience of absence and loss in people facing complicated grief (by its former, stigmatizing term: pathological or distorted grief), synchronizing the work of such heterogeneous groups of people, who have diverse loss history and individual (grief) habitus, is a real professional challenge. In such a work process the activity of doctors and health care workers can be supportive and could facilitate progress.

Keywords: complicated grief, psychosomatic disorders, grief aid

Zelena A. [Recognizing complicated grief from a doctor's point of view]. Orv Hetil. 2017; 158(36): 1426-1431.

(Beérkezett: 2017. július 3.; elfogadva: 2017. augusztus 3.)

A gyászfeldolgozó csoportokkal dolgozó szakemberek a komplikált gyásszal - korábbi, stigmatizáló terminológiával: patológiás vagy torzult gyásszal - küzdők legkülönfélébb hiány- és veszteségtapasztalatainak manifesztumaival találkoznak. Komoly szakmai kihívás, sőt inkább komplex feladat- és problémakör az ellátó orvosnak diagnosztizálni a komplikált gyászt, a gyászfeldolgozó csoportok vezetőinek pedig a csoportdinamika ívét fenn- tartó foglalkozást tartani úgy, hogy sokszor rendkívül heterogén összetételű, igen eltérő veszteséggel és egyéni gyászhabitussal rendelkező egyének alkotják ezen ad hoc módon szerveződő közösségeket. Az önsegítő csoportok szervezői sok esetben laikus vagy sorstárs segítők, de megtalálunk a szervezők között mentálhigiénés szakembert, teológust, szociális munkást és pszichológusokat, egyetemi hallgatókat egyaránt. A szervezés szakaszában 
olyan személyeket várnak a feldolgozócsoportba, akik elveszítették szerettüket, s úgy érzik, gondot okoz az elengedés, a búcsú, vagy éppen fájdalmukkal nem szeretnének egyedül maradni. E csoportok általában 10-12 alkalomra ad hoc módszerrel szerveződnek, legtöbbször igen sokszínű a veszteségélményt átélt résztvevők halmaza. Heterogén összetételü csoportot (nemek szerint, átélt veszteségtípus szerint stb.) szerveznek a legtöbben, de prae- és perinatalis veszteség esetén gyakori a tematikus csoport is. A csoport első két alkalmával lehetőség van a csatlakozásra, az ezt követő 10 alkalommal zárttá válik a csoport, hogy a bizalom létrejötte is enyhíthessen a fájdalmon, amely a veszteséggel jár együtt. Első olvasatra két egymástól eltérőnek tûnő esetleírással arra igyekszem rávilágítani, milyen sokféle olyan helyzet adódhat a praxisban, amikor a problémaérzékeny orvos segítségére lehet a gyász fájdalmától szenvedő betegének.

A téma honi és nemzetközi szakirodalma széles körű, a teljesség igénye nélküli felsorolással: 2017-ben megjelent szakkönyvében Hegedüs Katalin hosszú évtizedek betegágy mellett töltött gyakorlati és elméleti tapasztalatait vegyíti az orvosképzésben töltött oktató-kutató tapasztalathalmazával, s kiegészíti ezt számos szakkutatás eredményének feldolgozásával és értékelésével. Egyszerú summázata lenne a Létezik-e jó halál? [1] című kötet tartalmi ismertetésének, hogy „a jó halál éppen olyan, mint amilyennek a haldokló szeretné", de a jó halál keveseké - Hegedûs szerint. Ennek pedig számos oka van: a haldokló és/vagy családjának hárító magatartása, azon társadalmi tabuk és stigmák, amelyek az elmúlással és haldoklóval, s mi több, a gyászolókkal is kapcsolatosak. Erre a hárító mechanizmusra, családi és társadalmi tabura is fogok utalni az egyik alább bemutatott eset kapcsán. Pilling János 2008-ban közölt „Rossz hírek közlése” [2] című tanulmánya és $A$ gyász [3] címet viselő kötete a hazai szakirodalom legkurrensebbjei közé tartozik, de a hazai tanatológiai szakkutatások iskolateremtő tudósának, Polcz Alaine-nek az írásai sem maradhatnak ki e cikk bevezetőjéből.

Következetesen használom a komplikált gyász fogalmát tanulmányomban, amelyet Allen Wolfelt használt először 1991-ben, s számos hazai és nemzetközi kutató árnyalta, gazdagította a fogalomkör használatát. Lindemann „Az akut gyász tünettana és kezelése" [4] címü munkájában foglalta össze a gyász folyamatának állomásait, s használta a gyászmunka megnevezést. A komplikált gyásszal küzdőket segítő feldolgozócsoportok létszáma a halottak napja és mindenszentek, valamint a karácsonyi ünnepkör közeledtével mindig emelkedik, ennek magyarázata nem csak és kizárólag az elhunytakra való emlékezéssel, a szeretet ünnepének eljövetelével támasztható alá, hanem ott van a magyarázatok között a napsütéses órák számának radikális csökkenése, a téli idő beköszöntével felerősödő elmagányosodás érzésével megjelenő szezonális depresszió is. Tetten érhető ezen időszakban a gyászoló rendkívüli vulnerabilitása, dep- resszióra való hajlama. Kiss Kitty 2003-as, Depresszió és gyász-reakció. A tüneti kép összehasonlitása, különös tekintettel a szuicid viselkedésre címú PhD-értekezésében [5] ad értő és problémacentrikus leírást arra vonatkozóan, hogy a diagnosztikai kritériumok között hogyan lehet különbséget tenni, s könnyebb megkülönböztetni a szezonális depressziót és a komplikált gyász tüneteit. Kiss értekezésében ekként foglalja össze a DSM-IV szerinti kritériumokat a gyász időszakában jelentkező major depresszió elkülönítésére a normál gyásztól:

„- arra vonatkozó bűntudat, hogy a személy mit tehetett volna meg az elhunytért és mit nem tett meg;

- a halállal kapcsolatos gondolatok másként jelentkeznek, mint a túlélőknél általában, például neki vagy neki is meg kellett volna halnia;

- értéktelenségérzés;

- kifejezett pszichomotoros gátoltság;

- hosszas, jelentős funkciózavarok;

- inkább hallucinátoros élmények, szemben azzal a gondolattal, hogy hallja az elhunyt hangját, vagy futólag látni véli az elhunyt képmását” [5].

A két kórkép, a gyász és a depresszió között Kaplan [6] és Viedermann [7] az 1. táblázatban foglaltak szerint tesz különbséget.

A komplikált gyász fogalmának tárgyalásakor Kiss elegyíti a hazai és nemzetközi szakirodalom pszichoszoma-

1. táblázat |A gyász és a depresszió elkülönítése [6,7]

\begin{tabular}{ll}
\hline Gyász & Depresszió \\
\hline $\begin{array}{l}\text { Normális mértékű identifikáció } \\
\text { és enyhe fokú ambivalencia az } \\
\text { elhunyttal kapcsolatban }\end{array}$ & $\begin{array}{l}\text { Kóros túlazonosulás, fokozott } \\
\text { ambivalencia és tudattalan düh } \\
\text { az elhunyttal kapcsolatban }\end{array}$ \\
\hline $\begin{array}{l}\text { Sírás, testsúlyvesztés, csökkent } \\
\text { libidó, szociális visszahúzódás, } \\
\text { insomnia, a koncentrálóképesség }\end{array}$ & Hasonló tünetek \\
és a figyelem csökkenése & \\
\hline
\end{tabular}

\begin{tabular}{ll}
\hline $\begin{array}{l}\text { Az öngyilkossági gondolatok } \\
\text { ritkák }\end{array}$ & $\begin{array}{l}\text { Az öngyilkossági gondolatok } \\
\text { gyakoriak }\end{array}$ \\
\hline
\end{tabular}

Az önvád az elhunyttal való bánásmódra irányul, nincs

Az önvádlás széles körü, az általános értéktelenségérzés egyén azt gondolja, hogy ő egészében rossz vagy értéktelen

A környezet empátiát, szimpátiát Gyakran ingerültséget, tanúsít bosszúságot kelt az interperszonális kapcsolatokban

Az idő előrehaladtával a tünetek A tünetek nem csökkennek, csökkennek. A gyászoló érzi, hanem egyre súlyosabbá válnak, hogy a tünetek idővel enyhülni s még évek múltán is jelen fognak. A javulás általában hat lehetnek. A depresszióban hónapon belül beavatkozás nélkül is megtörténik szenvedő ember úgy érzi, hogy tünetei sohasem fognak enyhülni

Fokozott fogékonyság testi Fokozott fogékonyság testi betegségekre betegségekre

Megnyugtatásra, biztatásra reagál, szociális kapcsolatokba bevonható

Megnyugtatásra, biztatásra nem reagál, a szociális kapcsolatoktól elzárkózik

Antidepresszáns gyógyszerek Antidepresszáns gyógyszerek nem segítenek 
tikus tüneteinek felsorolását, osztályozásában a komplikált gyásznál felbukkanhat a veszteség tagadása, az érzelmek tagadása vagy kifejezési képtelensége, megjelenhet alvászavarok, izoláció, valóságérzékelési zavarok, depresszió, öngyilkosság, egyéb pszichiátriai, pszichoszomatikus és testi betegségek képében. A pszichoszomatikus betegségek közül a daganatos megbetegedéseket, magas vérnyomást, szív- és érrendszeri betegségeket, szerabúzust, ellenségességet, a reális értékítélet elvesztését és túlzott aktivitást említi [5].

Két esetismertetéssel arra igyekszem rávilágítani, hogy milyen fontos szerepe van a betegei nonverbális jelzéseire is szenzitív orvosnak - különösen a családorvosoknak - a komplikált gyász, a megrekedt gyászmunka időbeni felismerésében. Ugyanis a tajszámok mögötti egyéni traumákat és sorsokat, a betegek élet- és lakáskörülményeinek részleteit is ismerô gyógyítók katalizátorai lehetnek a megrekedt gyászmunka folytatásának, s számos pszichoszomatikus tünet mögött fedezhetik fel a valós traumatogén okot. Teszik mindezt már azzal a javaslattal is, hogy sorstárs vagy laikus segítő, mentálhigiénés szakember vagy pszichológus, esetleg pszichiáter szakorvos által vezetett feldolgozócsoport látogatását javasolják gyászoló betegeiknek. Fontos rögzíteni, hogy a gyászfeldolgozó csoportok szervezőinek kapcsolatot kell(ene) ápolnia az alapellátásban dolgozókkal, hiszen az információáramlás és támogató lehetőségek megismertetése közös érdek, a kommunikációs csatornák pedig sok esetben nem alkalmasak arra, hogy ezen információt hitelesen eljuttassák az alapellátásban dolgozó szakemberekhez, ezáltal a segítő lehetőségek ismeretségi spektruma sem a legszélesebb. A tanulmányba emelt esetleírások saját gyászcsoportvezetési tapasztalatokból származnak, annak szereplői történetük közléséhez szóbeli beleegyezésüket adták, keresztneveiket az anonimitásra vonatkozó szabályok betartásának érdekében megváltoztattam.

\section{Esetismertetések}

\section{Elsö páciens-egy halott, háromszori temetés}

Ilona 73 éves özvegy, férjét 34 év házasság után, nyolc hónappal első találkozásunk előtt vesztette el. Bár jó mentális státuszú, hangulata az esti órákban romló tendenciát mutat, saját maga kérte felvételét a pszichiátriai osztályra. Elmondása szerint este rátör a gyász súlyos terhe és öngyilkossági fantáziái vannak, de szuicid kísérlete nem volt. A nyolctagú feldolgozócsoport passzív résztvevője volt, átélt veszteségéről és gyászáról alig beszélt, társait reakciómentesen hallgatta; a 12 ülésesre tervezett csoportfoglalkozás első hét alkalmával szófukar volt. Általánosságok közlésével igyekezett legitimálni a csoporttagságát, ügyelve arra, hogy konkrét információt ne oszszon meg a csoporttal. (Annyit említett csupán, hogy férje betegségelőzmény nélkül, hirtelen halt meg.) Heteroanamnézis felvételével, az őt látogató fiától lehetett tudni szocioökonómiai státuszát, amely a teljesség igé- nye nélkül a következő: jó házasságban élt férjével, s bár közös gyermekük nem született, a nő előző házasságból származó fiúgyermekét nevelték közösen. A férj 10 évvel volt fiatalabb Ilonánál, s végtag-amputáció után egy fertőzés következtében halt meg, szemben a csoportban gyászoló nő által elmondott, betegségelőzmény nélküli halállal. Az elhunyt férj és az özvegy közti korkülönbséget tudva nem meglepő, hogy Ilona gyermeke alig hét évvel volt fiatalabb nevelőapjánál, s hiába volt 34 évig anyja társa a férfi, kapcsolatuk minősége nem patriarchális, inkább baráti volt. Ilona veszteség-közzétételében a nyolcadik foglalkozás hozott radikális változást, amikor két csoporttag között elhangozó dialógus egy kulcsszava, a 'halászlé' szó elhangzása indukálta a változást; mint egyfajta acting out, folyamatos, berekeszthetetlennek tûnő monológba kezdett, félbe is szakította társát. Impulzív monológjából kiderült, hogy házasságuk hosszú ideje alatt minden döntést egyedül hozott meg, kezelte a családi kasszát, minden hivatalos ügyet ő tartott kézben, míg férje a háztartást vezette, a karácsonyi menü elkészítése is a férj feladata volt. Történetének részletgazdag elmesélését követően büszkén kitért arra, hogy őrzi férje félig megfejtett keresztrejtvényét, pizsamáját, dohánytárcáját és olvasószemüvegét annak kedvenc fotelje mellett, a polcon. Mindent úgy hagyott, ahogyan azt férje odatette. Itt elvágólag megszűnt a történetmesélés. Átadta a szót csoporttársainak, s kérte, senki se kommentálja az általa elmondottakat. A csoporttal a következő összejöveteleken szóba került az emlékezés kereteinek kialakítása, jelen esetben 'memory box' és a levélírási technika (elhunytnak szóló levél) megvalósításával, ám a memory box ötlete Ilonánál merev elutasításba ütközött, ugyanis családtagjaival több konfliktusa volt abból, hogy a nagy múgonddal konzervált 'mauzóleumi sarokban' bármit elmozdítottak abból a helyzetból, ahogyan azt az elhunyt hagyta. A nemzetközi szakirodalom e jelenséget mumifikációnak nevezi [8], a komplikált gyász egy megnyilvánulási formájának tartja. Terápiás tanács tehát a gyászföldolgozást segítendő memory box készítése, amelyben helye lehet akár az elvesztett hozzátartozó személyes tárgyainak, jelen esetben az elhunyt szemüvegének, be nem fejezett keresztrejtvényének és cigarettásdobozának, s előnye továbbá az is, hogy bármikor elővehető, a gyászolt rokon emléke fölidézhető, ám nem traumatizálja a családtagokat. A csoportban egyre inkább megnyíló nő elmondta családorvosával meglévő - általa kivételesen bizalminak nevezett - nexusát, valamint azt, hogy valójában a doktornő tanácsára jár gyászfeldolgozó csoportba, s a doktornő az öngyilkossági fantáziáinak hátterében a magányát sejti. Teszi ezt a betegei szervi tünetein túli problémáira is fogékony, betegeivel élő kapcsolatot ápoló, a rájuk szánt minőségi időre figyelmet fordító családorvos, aki tud a gyászfeldolgozó csoportok létéról, s szükség esetén ezeket ajánlja is betegeinek. Ilonának ugyanis egy ponton megrekedt a gyászmunkája, $\mathrm{s}$ a nyolcadik csoportfoglalkozásig inkubálta és gátolta annak verbalizálását, hogy családja körében nem volt szo- 
kás a gyász megélése, és az erról való beszéd, a halál témája tabu volt [1].

A tanatológia nemzetközi esetismertetésében néhány helyen találni utalást az elhunyt és a gyászoló hozzátartozó efféle kapcsolattípusánál az elhunyt nyughelyével ápolt ambivalens viszonyra (azaz napi sírkertbe járás, élőszerü öndialógus a sírhanttal, étel sírkőre helyezése stb.), így Ilonánál irányított kérdésekkel - de figyelve arra, hogy ne legyen retraumatizáló a beszélgetés sem az ő, sem más csoporttagok számára - a dialógust ebbe az irányba igyekeztem terelni. Kiderült eközben, hogy az asszony folyamatos gondoskodási kényszerben éli mindennapjait házassága első évétől kezdődően; akkor tartja magát fontosnak, ha egy nála elesettebbről gondoskodhat. Férje halála után újratemetési gesztusaival érezte szükségét „gondoskodnia” az elhunytról. Mi sem jelzi ezt jobban, mint hogy az első nyughelyet azért nem találta megfelelőnek, mert gazos volt a sírhantig vezető út. Ezt követően méltatlannak érezte, hogy a sírásók mellett csak ő volt ott az urna kihantolásakor és újratemetésekor, s a pap és a szúkebb hozzátartozók nem kísérték utolsó útjára néhai férjét. Arra az elhatározásra jutott, hogy a gyászolókat meghívja a harmadik temetésre, s újabb ceremóniát szervezett. A korábban kommunikált gyászteher azonban ettől kezdve már nem verbalizálódott, az asszony „önmantrázó” mondatai a következők lettek: „Találnom kell egy embert magam mellé.” Úgy vélem, az újratemetésekkel kapcsolatos történetszál felfejtése a gyászmunka folytatásának letéteményese lett, s a trauma a feldolgozási szakaszba lépett. Remélhetőleg a közeljövőben pedig a poszttraumás növekedés [9] is kezdetét veheti majd. Ilona ugyanis férje nyughelyét azért bontatta fel és temettette el a hamvakat újra és újra, mert énkonstrukciójának hálóján keletkezett seb férje halálával: nem érezte többé hasznosnak és nélkülözhetetlennek magát. A szakirodalomban megjelenik ilyen esetekre a terápiás háziállat (kutya) javaslata a gyászolók számára, de Ilonának ez nem volt opció, komplexebb gondoskodási feladat az, ami elmondása szerint újból képes lehet megkonstruálni személye szükségességét. Sajnos e pontig a gyászban való személyiségfejlődési lehetőségét sem lehetett tetten érni nála, hiszen veszteségélménye komplexebb egy hozzátartozója elvesztésénél: az ő személyiségkonstrukciója fog szétesni laikus öndiagnózisa szerint, már verbalizálja azt is, hogy saját magát is gyászolja özvegyi státusza mellett. A gyászfeldolgozó csoport munkáját befejeztük, de az osztály munkatársaitól visszajelzést kaptam hetekkel később: Ilona otthonába fogadta a krónikus osztály egy demens férfibetegét az idős férfi hozzátartozóinak támogatásával, azóta nem jár be az osztályra, gyógyszerszedését családorvosa támogatásával felfüggesztette. Annak megítélésében nehéz döntésre jutnom, hogy ez a gyászban való személyiségfejlődés megjelenése, vagy inkább a gondoskodás új személyre történő áthelyezésének manifesztuma. Véleményem szerint inkább az utóbbi, hiszen a feldolgozócsoportban lévő segítő beszélgetések, az osztályon dolgozó pszichi- áterrel való egyéni terápia nem vezetett eredményre, sokkal inkább az volt támogató, ha a beteg újból a számára biztonságot jelentő közegbe „helyezte magát”.

Bár a fent bemutatott eset kapcsán a gyásztámogatás keretei meglehetősen korlátozottak voltak, a gyászoló nő családorvosával sikerült egy olyan terápiás teamet létrehozni (családorvos, pszichiáter és gyászcsoportvezető), ahol a társas támogatásra és a gyászfeldolgozó csoportra a családorvos hívta fel a gyász fájdalmától szenvedő beteg figyelmét. Kiemelendő tehát, hogy a beteg metakommunikációjára szenzitív doktorok szerepe rendkívüli annak időbeni diagnózisában, hogy a gyászolónak segítségre van szüksége, gyászmunkája megrekedt. A csoporttagok párbeszéde pedig gyújtópontja lett a gyászoló eddig gátolt megnyilatkozásának, amelynek során eljutott annak felismeréséig, hogy mi akadályozza őt újból önmagára találásában. Természetesen mindemellett szükséges rögzíteni, hogy a gondoskodási kényszerben élő asszonynak számos más lehetősége is lett volna arra, hogy hasznosnak és tevékenynek érezze magát, s ennek támogatására egy egyéni, s hosszabb segítő beszélgetésekre való nyitottsága esetén akár lehetősége is nyílt volna, de erre a férfi magához fogadását követően már nem volt fogadókész. A gyászcsoportban a cél a megrekedt gyászmunka folytatására irányuló kísérlettétel, s Ilona esetének e tanulmányba emelése kapcsán pedig annak hangsúlyozása, hogy a kezelőorvosok gyászcsoportok létéről való tudása hihetetlen szupportív erővel bír.

\section{Második páciens - sirbely a kertben}

Andrea egy országhatárhoz közeli település lakója, ötvenes éveinek közepén jár. Alvászavarától és rossz kedélyállapotától évek óta szenved, huzamosabb ideje altatóval tud csak aludni. Egy helyettesítő orvos látta el otthonában eszméletvesztése miatt a gyászcsoport előtti hónapban, az ő javaslatára keresett egy gyászfeldolgozó csoportot. Bemutatkozásakor elmondta: húsz évvel ezelőtt tizenéves fiúgyermeke fulladt meg úszás közben, őt gyászolja férjével közösen. Másik gyermeke, véleménye szerint, nem vesz tudomást elhunyt testvéréről. Andrea szerint „törölte” testvérének emlékét, saját gyermekeinek el sem mondta, hogy volt egy testvére. Kezdetét vette a közös munka, a csoport megindult a közös úton. A feldolgozócsoportban folyó munka során egy terápiás eszköz, amikor a szakemberek azt tanácsolják a gyászolónak: írjanak elhunyt hozzátartozójuknak szóló levelet megszólítással, élőszerüen, mintha a megszólítottnak életében írta volna, s a címzett megkaphatná, elolvashatná. Ezt kértem én is a csoporttól, s a feladatleírás fontos része volt még, hogy a 'mit mondtam volna el még neked', 'miért kérek tóled bocsánatot' vagy 'mit szeretnék, hogy tudj' gondolatok közlése se maradjanak ki. Lehetőség szerint szerettük nyughelyén olvassák föl a csoporttagok a levelet, legyen az temetői sírhant vagy a szimbolikus búcsú helyszíne: vízpart vagy kedvenc kirándulóhely. A levelet felolvasása 
(értsd: eljuttatása) után semmisítsék meg, mivel az üzenet célba ért [10]. E csoportfeladat kitűzését követő alkalommal társaik előtt többen beszámoltak élményeikről. Ilyenkor számos szkeptikus is pozitív élményként értékelte a levél megírását, majd a sírkertben való felolvasását. Andrea is elmesélte a levél felolvasásának személyes történetét, de történetmondásában sírkertről nem esett szó, mondataiban a kert és otthon szavak szerepeltek feltúnően sokszor. Ekkor pedig a gyászcsoport vezetőjeként előttem is világossá vált a helyettesítő családorvos motivációja, miért javasolta Andreának a tapintatos doktor a gyászcsoport látogatását. Ugyanis a nő otthonában szerzett olyan információ birtokában volt a doktor, ami bár Andrea számára evidens, a gyásza és túlélő gyermekével kapcsolatos konfliktusa kapcsán eddig nem kommunikálta senkinek sem. Elhunyt tinédzser fia hamvait a kertjük közepén őrizte egy kôhalom, mint síremlék, éppen a kerti hinta és homokozó mellett. A többi családtag otthoni nyughelyhez való viszonyára irányuló implicit kérdésfeltételek, a szimbolikus búcsú és elengedés kérdéseinek közös, olvasmányélmények alapján való csoportbéli tárgyalása pedig jó irányba terelte a történéseket. Felismerésre és családi döntésre sarkallta a családot: az utolsó foglalkozáson Andrea elmondta, hogy aznap volt a fia urnájának a nagyszülők sírboltjába helyezése, amelyet gyermeke magából kitörő zokogással, testvére gyászának megélésével élt át. Ez volt az eset jó irányba fordulásának pontja, ugyanis fontos rögzíteni, hogy az elhunyt hozzátartozó földi maradványaival kapcsolatos kérdések, az otthoni urnaőrzéssel vagy akár temetőválasztással kapcsolatos eltérő viszonyulások komoly konfliktusforrások lehetnek családon belül is. Hiszen a gyermekkorú testvérnek a tragédia idején még nem volt beleszólása abba, hogy szülei elhunyt fiútestvére hamvait hol helyezik örök nyugalomra, de felnőttként már dönthetett afelől, hogy saját gyermekeit hintáztatja-e sírhant melletti hintán a nagyszülők meglátogatásakor, s elmondja-e kisgyermekeinek, hogy a nagymama miért visz virágot arra a kóhalomra, s miért nem szabad annak környékén hangoskodni, a kövekkel játszani. Ebben az esetben az otthoni hamvak őrzése tényének felismerése lehetett elindítója a segítő folyamatba való bekapcsolódásnak, hiszen az otthoni urnaőrzéssel kapcsolatos ambivalens viszonyulásokra a fenti eset kapcsán az anyát otthonában ellátó orvos figyelt föl. Számos haláleset kapcsán találkozunk azzal a helyzettel, hogy a veszteséget átélt hozzátartozók családorvosuk segítségét és véleményét kérik a temetéssel és gyásszal kapcsolatosan. Az érzékeny téma felszínre kerülésekor fontos felhívni a gyászolók figyelmét egyfajta jó gyakorlatként arra, hogy az otthoni urnaörzés vagy eltemetés milyen következményekkel járhat. Megemlítendő, hogy kívánatos a rokonok és barátok részére a kegyeletgyakorlás biztosításának a lehetősége, valamint az is, hogy a gyászfeldolgozás során milyen nehézségeket jelenthet az e temetési forma melletti döntés.

\section{Megbeszélés, összegzés}

Úgy vélem, a gyásztámogatás és feldolgozócsoportok csupán néhány aspektusára tértem ki e cikkben, de a két eset ismertetése rávilágít arra, hogy a gyásztámogatás nem múködhet a családorvosi rendszer támogató tevékenysége nélkül. A vizsgálatom homlokterében lévő esetek arra világítottak rá, hogy a fókuszban lévő orvosok számos, az alapellátást kiegészítő tevékenységet végeznek, és óriási szerepet vállalnak a mentális problémák feltárásában, a terápiás lehetőségek megismertetésében. A komplikált gyászra utaló tüneteket Kiss Kitty alaposan tárgyalja [5], s e kórkép gyanúja esetén számos segítő lehetőség kínálkozik: praenatalis és perinatalis veszteséget átélt szülők számára a PIC-centrumok mellett müködnek speciális feldolgozócsoportok, s az e témával foglalkozó társadalmi szervezetek száma is gyarapodik (Angyalok szülei program). Vallásos gyászolók ma már több felekezetben találnak szakképzett lelki segítőt, gyásszal foglalkozó egyházi személyt, ugyanis több egyház hirdet teológusainak egyetemi kutatóhelyek által szervezett gyász- és lelki segítői képzéseket. De felekezeti hovatartozástól független feldolgozócsoportok is több szinten szerveződhetnek: laikus és sorstárs segítők, úgynevezett önkéntes gyászcsoportvezetők is tartanak csoportos foglalkozást, s mentálhigiénés szakemberek, tanatológiával foglalkozó kutatók, pszichológusok is szerveznek gyászolóknak hirdetett csoportokat. Komplexebbnek tûnő gyásztrauma esetén pedig klinikai szakpszichológusok és gyászterapeuták, pszichiáter szakorvosok foglalkoznak a gyászolókkal. Mint a fenti két eset ismertetéséből is látszik: a betegek szervi tünetein túli életeseményeket, sorsokat, a betegek körülményeit is ismerő gyógyítók katalizátorai lehetnek a megrekedt gyászmunka folytatásának, s számos pszichoszomatikus tünet mögött fedezik fel a valós traumatogén okot.

Anyagi támogatás: A közlemény megírása és a kapcsolódó kutatómunka anyagi támogatásban nem részesült.

A szerző a cikk végleges változatát elolvasta és jóváhagyta.

Érdekeltségek: A szerzőnek nincsenek érdekeltségei.

\section{Irodalom}

[1] Hegedûs K. Is there a good death? [Létezik-e jó halál?] Oriold és Társai Kft., Budapest, 2017; 7-15. [Hungarian]

[2] Pilling J. Riporting bad new. In: Pilling J. (ed.) Medical communication. [Rossz hírek közlése. In: Pilling J. Orvosi kommunikáció.] Medicina Könyvkiadó, Budapest, 2008; pp. 306-334. [Hungarian]

[3] Pilling J. (ed.) The greif. [A gyász.] Medicina Könyvkiadó, Budapest, 2003. [Hungarian]

[4] Lindemann E. Symptomatology and management of acute grief. Am J Psychiatry 1944; 151(6 Suppl): 155-160.

[5] Kiss K. Depression and grief-reaction. Symptomatological comparison especially of suicidal symptoms. PhD Thesis. [Depresszió 
és gyász-reakció. A tüneti kép összehasonlítása, különös tekintettel a szuicid viselkedésre. PhD-tézis.] Semmelweis Egyetem, Egészségtudományok Doktori Iskolája, Budapest, 2003. [Hungarian]

[6] Kaplan HI. Bereavement and death. In: Kaplan HI (ed.) Pocket Handbook of Clinical Psychiatry. Lippincott, Williams \& Wilkins, Oxford, 1990; pp. 220-222.

[7] Viedermann M. Grief: normal and pathological variants. Am J Psychiatry $1995 ; 152: 1-4$.

[8] Devan GS. Managent of grief. Singapore Med J. 1993; 34: 445448.

[9] Calhoun LG, Tedeschi RH. The foundations of posttraumatic growth: An expanded framework. In: Calhoun LG, Tedeschi
RG. (eds.) Handbook of posttraumatic growth. Research and practice. Psychology Press, New Jersey, 2006; pp. 3-23.

[10] Zelena A. Mourning techniques and end-of-life planning. [Rózsadombról albérletbe: Gyászföldolgozási technikák és életvégi tervezés.] Mindennapi Pszichológia 2016; 8: 54-55. [Hungarian]
(Zelena András dr., Budapest, Diósy Lajos u. 22-24., 1165 e-mail:dr.zelenaa@gmail.com)

Az Orvosi Hetilap 2017, 158, 1239. oldalán (31. szám) megjelent OH-kvízre három helyes megfejtés érkezett.

A beküldők: Dr. Bíró László (Budapest), Dr. Janik Leonárd (Budapest) és Dr. Somogyi Erzsébet (Miskolc).

A nyerteseknek szívböl gratulálunk.

A nyereményüket - egy, az Akadémiai Kiadó webáruházában kedvezményes vásárlásra jogosító kupont - e-mailen küldjük el.

\section{Új fejlesztés az egészségügyben dolgozók, tanulók részére!}

A magyar nyelvứ szakirodalmi keresőszolgáltatás

\section{Mi a NOTA? \\ Napivizit Orvosi Tudástár Alkalmazás}

Mit tud a NOTA portál?

Megkönnyíti a magyar nyelvű szakirodalmi források keresését.

Eszköztöl függetlenül, akár okostelefonról, a betegágy mellett állva is használható.

\section{Miben kereshet a NOTA-val?}

Az Akadémiai Kiadó folyóirataiban: Orvosi Hetilap, Magyar Sebészet, Mentálhigiéné és Pszichoszomatika.

Más kiadók magyar nyelvű

szakfolyóirataiban: pl. Lege Artis Medicinae, Hypertonia és Nephrologia, Ideggyógyászati Szemle.

A hatályos szakmai irányelvekben

Magyar nyelvű kérdésekre adott ango nyelvű találatokban, a PubMeden.

\section{nota.hu}

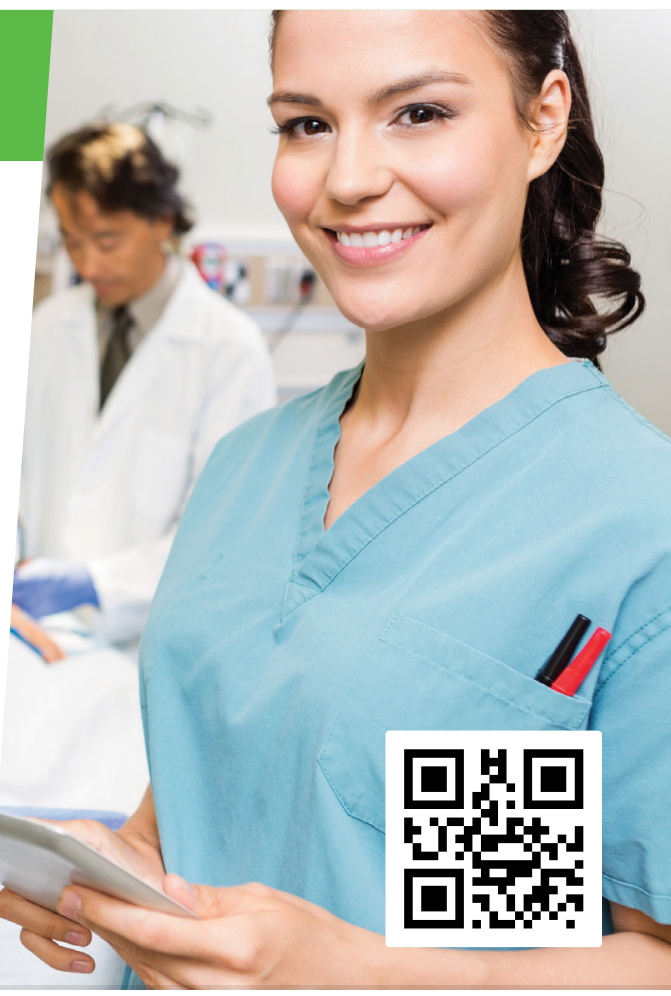

\section{Akadémiai Kiadó}

A Wolters Kluwer Csoport tagja

1117 Budapest, Prielle Kornélia u. 21-35. / Telefon: (1) 464-8246 